\title{
Kajian Autekologi Pigafetta elata (Mart.) H. Wendl. (ARECACEAE) pada Hutan Pegunungan Dongi-Dongi di Kawasan Taman Nasional Lore Lindu Sulawesi Tengah
}

\section{A Study of Autecology Pigafetta elata (Mart.) H. Wendl. (Arecaceae) On Dongi-Dongi Mountain Forest In The Lore Lindu National Park Area, Central Sulawesi}

\author{
Mohammad Rezha Aras*, Ramadhanil Pitopang dan I Nengah Suwastika \\ Jurusan Biologi FMIPA, Universitas Tadulako \\ Kampus Bumi Tadulako Jl. Soekarno-Hatta Km.9 Palu, Sulawesi Tengah 94118
}

\begin{abstract}
The Study of Autecology Pigafetta elata (Mart.) H. Wendl on Dongi-dongi Mountain Forest in the Lore Lindu National Park (LLNP) Area Central Sulawesi was conducted from May to July 2016. The aim of this study is to find out autecology such as abiotic and biotic factors of P. elata in Dongi-dongi Mountain forest of Lore Lindu National Park Area. Abiotic factors such as temperature and relative humidity were measured using thermohygrometers, light intensity maeasured by Lux meter, $\mathrm{pH}$ and humidity soil were measured using Soil Taster. Meanwhile, rainfall data was obtained from the weather monitoring stations Agency for Meteorology, Climatology and Geophysics Mutiara Sis Al-Djufrie Palu Airport. Nitrogen $(\mathrm{N})$, Phosporus $(\mathrm{P})$ and Potassium $(\mathrm{K})$ concentrations in the soil in where $P$. elata growt, were analysed based on khedjhal method and extraction with HCL 25\% method. Plants vegetation constituent mountain forest around $P$. elata area was determined based on multiple plots systematically method and analysed with formula vegetation analysis according by DumboisMuller and Ellenberg. The research result in the Dongi-dongi LLNP showing, daily temperature average was $2,20^{\circ} \mathrm{C}$, relative humidity was $84,84 \%$, monthly rainfall from May to July 2016 was $205 \mathrm{~mm}, 134 \mathrm{~mm}$ dan $35 \mathrm{~mm}$ and light intensity rangeing from $297-6125$ lux with an average of 1985 lux. P. elata can be grow on N, P, K soil with concentrations of $0,08 \% \mathrm{~N}-T o t, 39,16 \mathrm{mg} / 100 \mathrm{~g}$ of P-Tot and 34,22 mg/100g of K-Tot. Vegetation analysis on a tree level was dominated by Castanopsis acuminatissima (Blume) A. DC. with Important Value (IV) was $34,23 \%$, a pole level was dominated by Eurya acuminata DC. with IV(\%) was $64,02 \%$, vegetation of sapling level was dominated by Trema orientalis (L.) Blume with IV $(\%) 64.97 \%$ and Ageratum conyzoides L. with IV(\%) $17.88 \%$ which has dominated seedling level.
\end{abstract}

Keywords : Autecology, Pigafetta elata (Mart.) H. Wendl, Lore Lindu National
Park (LLNP).
ABSTRAK
Penelitian tentang "Kajian Autekologi Pigafetta elata (Mart.) H. Wendl. (Arecaceae)
pada Hutan Pegunungan Dongi-dongi di Kawasan Taman Nasional Lore Lindu Sulawesi
Tengah" telah dilakukan dari bulan Mei sampai Juli 2016 dengan tujuan untuk mengetahui
autekologi berupa kondisi faktor lingkungan abiotik dan biotik dari P. elata pada hutan

Coresponding author: "Mohammad Rezha Aras" mohrezhaaras@gmail.com 
pegunungan Dongi-dongi di kawasan TNLL Sulawesi Tengah. Faktor lingkungan seperti suhu dan kelembaban relatif diukur dengan Termohygrometer, intensitas cahaya diukur dengan Lux meter, $\mathrm{pH}$ dan kelembaban tanah diukur dengan Soil Taster. Sementara, data curah hujan diperoleh dari stasiun pengamatan cuaca Badan Meteorologi Dan Geofisika Bandar Udara Mutiara Sis Al-Djufrie Palu. Konsentrasi nitrogen, posfor dan kalium di dalam tanah di mana $P$. elata tumbuh diukur dengan metode khedjhal dan metode ekstraksi dengan HCL 25\%. Vegetasi tumbuhan penyusun hutan pegunungan di sekitar P. elata ditentukan dengan metode petak ganda secara sistematis dan dianalisis dengan rumus analisis vegetasi menurut Dumbois-Muller dan Ellenberg. Hasil penelitian di Dongi-dongi TNLL menunjukkan suhu udara harian rata-rata $21,20^{\circ} \mathrm{C}$, kelembaban relatif $84,84 \%$, curah hujan bulanan Mei sampai Juli 2016 yaitu $205 \mathrm{~mm}, 134 \mathrm{~mm}$ dan $35 \mathrm{~mm}$ dan intensitas cahaya berkisar 297 - 6125 lux dengan rata-rata 1985 lux. P. elata dapat tumbuh di N, P, K tanah dengan konsentrasi yaitu N-Tot 0,08 \%, P-Tot 39,16 mg/100g dan K-Tot 34,22 mg/100g. Analisis vegetasi pada tingkat pohon, vegetasi didominasi oleh Castanopsis acuminatissima (Blume) A. DC. dengan INP 34,23 \%, tingkat tiang Eurya acuminata DC. INP 64,02\%, tingkat pancang Trema orientalis (L.) Blume INP 64.97\% dan Ageratum conyzoides L. INP $17.88 \%$ mendominasi vegetasi pada tingkat semai.

\section{Kata kunci : Autekologi, Pigafetta elata (Mart.) H. Wendl, Taman Nasional Lore Lindu (TNLL).}

\section{Latar Belakang}

Sulawesi memiliki tingkat endemisitas palem yang tinggi (72\%), dimana 68\% spesies dan $58 \%$ genus palem yang tumbuh di bioregion ini adalah asli Sulawesi. Beberapa spesies palem Sulawesi yang bersifat endemik adalah Pigafetta elata Becc., Licuala celebica Miq., serta beberapa spesies rotan seperti taimanu (Korthalsia celebica), tohiti (Calamus inops Becc. ex. Celebicus Becc.), batang (Calamus zollingerii Becc.), Calamus minahassae, Calamus koordersianus Becc., Calamus symphisipus Mart., dan lain-lain (Mogea, 2002).

Genus Pigafetta merupakan salah satu dari suku palem-paleman yang terdiri dari dua jenis yaitu Pigafetta filaris yang tumbuh di Maluku (Moluccas) dan Papua Nugini (New Guinea) dan Pigafetta elata yang merupakan jenis yang bersifat endemik di Sulawesi (Dransfield et al., 2008).

Taman Nasional Lore Lindu merupakan salah satu Taman Nasional di Indonesia yang terdapat di Propinsi Sulawesi Tengah dengan luas 217.991,18 Ha. Kawasan konservasi terbesar di Sulawesi Tengah dan merupakan salah satu perwakilan untuk keanekaragaman hayati di bioregion Wallacea, merupakan salah satu dari 10 hotspot untuk keanekaragaman hayati yang unik di dunia. Taman Nasional Lore Lindu telah mendapat banyak predikat atau julukan karena potensi dan keunikan yang dimilikinya, di antaranya adalah sebagai cagar biosfer pada tahun 1977 oleh MAB-UNESCO. Taman Nasional Lore Lindu memiliki keanekaragaman jenis flora yang sangat tinggi, hal ini tersirat dari berbagai laporan inventarisasi yang 
dilakukan beberapa ahli botani, akan tetapi informasi tentang taksonomi, ekologi dan kajian etnobotaninya belumlah lengkap (Pitopang, 2012). Ekosistem Hutan Pegunungan mendominasi wilayah Taman Nasional Lore Lindu ini dengan luas mencapai 90\%, selebihnya merupakan ekosistem hutan dataran rendah dan setidaknya dihuni oleh sembilan tipe vegetasi (Pitopang, 2006). Menurut Purwaningsih dan Razali (2005), Lore Lindu menyimpan jenis-jenis tumbuhan yang bersifat endemik, namun belum banyak diungkapkan. Salah satu tumbuhan yang bersifat endemik Sulawesi yang tumbuh di kawasan Taman Nasional Lore Lindu adalah Pigafetta elata (Mart.) H. Wendl.

John Dransfield (1998), menyatakan bahwa pertama kali melihat tumbuhan ini di daerah Sulawesi Utara. menemukan perbedaan antar $P$. filaris dan $P$. elata sehingga menyatakan bahwa tumbuhan Pigafetta mempunyai dua jenis dan salah satunya merupakan tumbuhan yang bersifat endemik di Sulawesi. Tetapi dalam hal ini, data mengenai jenis P. elata (Mart.) $\mathrm{H}$. Wendl., seperti data ekologi spesifik berupa faktor lingkungan abiotik dan biotiknya masih belum ada di publikasikan. Berdasarkan hasil obvervasi, tumbuhan ini juga tumbuh di area hutan pegunungan Taman Nasional Lore Lindu tepatnya di area Dongi - dongi yang merupakan wilayah yang masuk kawasan TNLL dan secara administratif merupakan bagian wilayah Desa Sedoa. Olehnya, maka perlu adanya kajian autekologi $P$. elata pada kawasan Taman Nasional Lore Lindu. Menurut Sutomo dan Mukaromah (2010), bahwa tiap spesies memiliki apa yang disebut "ecologic individuality" atau kebutuhan relung hidup yang spesifik. Dengan demikian mempelajari autekologi dari suatu spesies sangat diperlukan.

Di samping itu, saat ini keberadaan $P$. elata sendiri telah terusik dengan adanya aktivitas masyarakat sekitar yang dapat mengancam kelestarian dari tumbuhan ini seperti penebangan liar, pembukaan lahan perkebunan dan sebagainya, sehingga berdampak pada pelestarian tumbuhan ini secara langsung. Dongi-dongi merupakan area tempat tumbuhnya $P$. elata yang termasuk dalam wilayah Taman Nasional Lore Lindu dan merupakan bagian dari Desa Sedoa. Area Dongi-dongi terentang sepanjang kilometer 66-79 di jalan provinsi pada ruas Palolo-Napu. Dongi-dongi adalah area dataran tinggi dan sebagian besar termasuk dalam area hutan pegunungan, berada pada ketinggian $1.100 \mathrm{~m}$ dpl hingga $1.500 \mathrm{~m}$ dpl di daerah hulu aliran Sungai Sopu - Gumbasa. Area Dongi-dongi sebagian lahannya digunakan untuk lahan pertanian dan pemukiman. Sebagian besar warga yang berada Dongi-dongi merupakan 
pemukim liar dan perambah hutan di Kawasan Taman Nasional Lore Lindu. Data dari Balai Besar Taman Nasional Lore Lindu luas perambahan hutan khususnya areal Dongi-dongi mencapai 3800 hektar. (Dephut, 2015).

Berdasarkan kabar dari Departemen Kehutanan Balai Besar Taman Nasional Lore Lindu (2016) pula, bahwa telah terjadi penebangan liar yang mana bertujuan untuk pembukaan lokasi pertambangan pada kawasan hutan Taman Nasional Lore Lindu tepatnya di Dongi-dongi.

Berdasarkan hal-hal tersebut di atas, untuk menjaga kelestarian dari $P$. elata sebagai tumbuhan yang bersifat endemik di Sulawesi, maka perlu dilakukan penelitian tentang Kajian Autekologi P. elata (Mart.) H. Wendl. (Arecaceae) pada Hutan Pegunungan Dongi-dongi di Kawasan Taman Nasional Lore Lindu Sulawesi Tengah.

Penelitian ini diharapkan dapat memberikan informasi dan melengkapi data ilmiah tentang faktor lingkungan abiotik dan biotik pada $P$. elata., serta diharapkan dapat bermanfaat dalam peningkatan ilmu pengetahuan dan upaya melestarikan tumbuhan ini sebagai tumbuhan yang bersifat endemik di Sulawesi khususnya pada hutan pegunungan Dongi-dongi di kawasan Taman Nasional Lore Lindu Sulawesi Tengah.

\section{METODOLOGI PENELITIAN}

\section{Waktu dan Tempat Penelitian}

Penelitian ini dilaksanakan pada bulan Mei sampai bulan Juli 2016 di hutan pegunungan Dongi-dongi (Sekitar jalan Palu-Napu) Kawasan Taman Nasional Lore Lindu Sulawesi Tengah.

\section{Bahan dan Metode Penelitian}

Metode yang digunakan adalah survey eksploratif yaitu menjelajahi area lokasi penelitian habitat P.elata di Hutan Pegunungan Dongi-Dongi Kawasan TNLL.

Faktor lingkungan seperti suhu dan kelembaban relatif diukur dengan termohygrometer, intensitas cahaya diukur dengan lux meter, $\mathrm{pH}$ dan kelembaban tanah diukur dengan Soil Taster. Sementara, data curah hujan diperoleh dari stasiun pengamat cuaca Badan Meteorologi Dan Geofisika Bandar Udara Mutiara Sis Al-Djufrie Palu. Konsentrasi nitrogen $(\mathrm{K})$, posfor $(\mathrm{P})$ dan kalium $(\mathrm{K})$ di dalam tanah di mana $P$. elata (Mart.) H. Wendl. tumbuh diukur dengan metode khedjhal dan metode ekstraksi dengan HCL $25 \%$.

Vegetasi tumbuhan penyusun hutan pegunungan di sekitar $P$. elata ditentukan dengan metode petak ganda secara sistematis "Purposive Sampling".

Untuk pengambilan sampel tanah, menggunakan metode contoh tanah terganggu (disturbed soil sample), dengan pengambilan contoh tanah secara acak 
sederhana (Simple Random Sampling)

(Suganda dkk, 2006).

\section{Analisis Data}

Data vegetasi tumbuhan di lapangan disajikan secara kuantitatif dengan dianalisis dengan rumus analisis vegetasi menurut Dumbois-Muller dan Ellenberg (Soerianegara dan Indrawan, 1993), sebagai berikut :

- Kerapatan (K)

$$
\mathrm{K} \quad \frac{\text { Jumlah individu jenis (i) }}{\text { Luas total petak }}
$$

- Kerapatan relatif (KR)

$$
\text { KR } \quad \frac{\text { : Kerapatan suatu Jenis (i) }}{\text { Kerapatan total semua jenis }} \times 100 \%
$$

- Frekuensi (F)

F : Jumlah petak individu jenis(i) Jumlah total petak

- Frekuensi relatif (FR)

FR : $\quad \frac{\text { Frekuensi suatu jenis (i) }}{\text { Frekuensi total semua jenis }} \times 100 \%$

- Luas bidang dasar: $1 / 4 . \pi . \mathrm{d}^{2}$

- Dominansi (D)

D : $\frac{\text { Luas bidang dasar suatu jenis (i) }}{\text { Luas total petak }}$

- Dominansi relatif (DR)

DR : $\frac{\text { Dominansi suatu jenis (i) }}{\text { Dominansi total semua jenis }} \times 100 \%$

- Nilai Penting (INP)

INP : KR + FR + DR (Pohon, tiang dan pancang) dan KR + FR (semai atau seedling).

Untuk menentukan keanekaragaman jenis vegetasi ialah dengan menghitung indeks keanekaragaman jenis menggunakan rumus menurut ShannonWhiener (Ludwig and Reynold, 1988), sebagai berikut :

$$
\boldsymbol{H}^{\prime}=-\sum_{i=1}^{n}\left[\frac{n i}{N} \ln \frac{n i}{N}\right]
$$

\section{HASIL DAN PEMBAHASAN}

\section{Faktor Lingkungan Abiotik}

Tempat atau lokasi pengambilan sampel berada pada hutan pegunungan area Dongi-dongi dengan ketinggian berkisar antara 1200 - $1500 \mathrm{~m}$ dpl. Titik koordinat pengambilan sampel terletak pada area yang ditumbuhi P. elata. Perletakan plot di lokasi penelitian adalah sebagai berikut :

\begin{tabular}{|c|c|c|}
\hline \multirow{2}{*}{$\begin{array}{c}\text { Lokasi } \\
\text { penelitian }\end{array}$} & \multicolumn{2}{|c|}{ Titik Koordinat } \\
\hline & Lintang Selatan & Bujur Timur \\
\hline Plot 1 & LS $1^{0} 18^{\prime} 42,40^{\prime \prime}$ & $\begin{array}{l}\text { BT } \\
120^{0} 17^{\prime} 3,70^{\prime},\end{array}$ \\
\hline Plot 2 & LS $1^{0} 18^{\prime} 42,20^{\prime \prime}$ & $\begin{array}{l}\text { BT } \\
120^{0} 17^{\prime} 2,10,\end{array}$ \\
\hline Plot 3 & LS $1^{0} 18^{\prime} 47,90^{\prime \prime}$ & $\begin{array}{l}\text { BT } \\
120^{0} 17^{\prime} 2,00^{\prime},\end{array}$ \\
\hline Plot 4 & LS $1^{0} 18^{\prime} 31,80^{\prime \prime}$ & $\begin{array}{l}\text { BT } \\
120^{0} 16^{\prime} 56,40^{\prime},\end{array}$ \\
\hline Plot 5 & LS $1^{0} 18^{\prime} 25,20^{\prime \prime}$ & $\begin{array}{l}\text { BT } \\
120^{0} 16^{\prime} 50,20^{\prime},\end{array}$ \\
\hline
\end{tabular}

Tabel 1 Lokasi pengambilan sampel beserta titik koordinat

Pengukuran faktor lingkungan abiotik meliputi suhu udara dan kelembaban udara dilakukan tiap jam selama 24 jam (1 hari). Sedangkan pH dan kelembaban tanah dilakukan pengukuran pada setiap plot dengan pengambilan data pengukuran di dekat pohon P. elata (Mart.) H. Wendl. Pada pengukuran intensitas cahaya dilakukan perjam selama 12 jam pada saat pagi hingga sore hari. Sedangkan data iklim curah hujan diperoleh secara sekunder dari Badan Meteorologi, Klimatologi dan Geofisika (BMKG) Bandar Udara Mutiara Sis Al Djufrie Palu. Berikut ini merupakan data 
faktor lingkungan abiotik yang disajikan dalam tabel 2 sampai dengan tabel 4 :

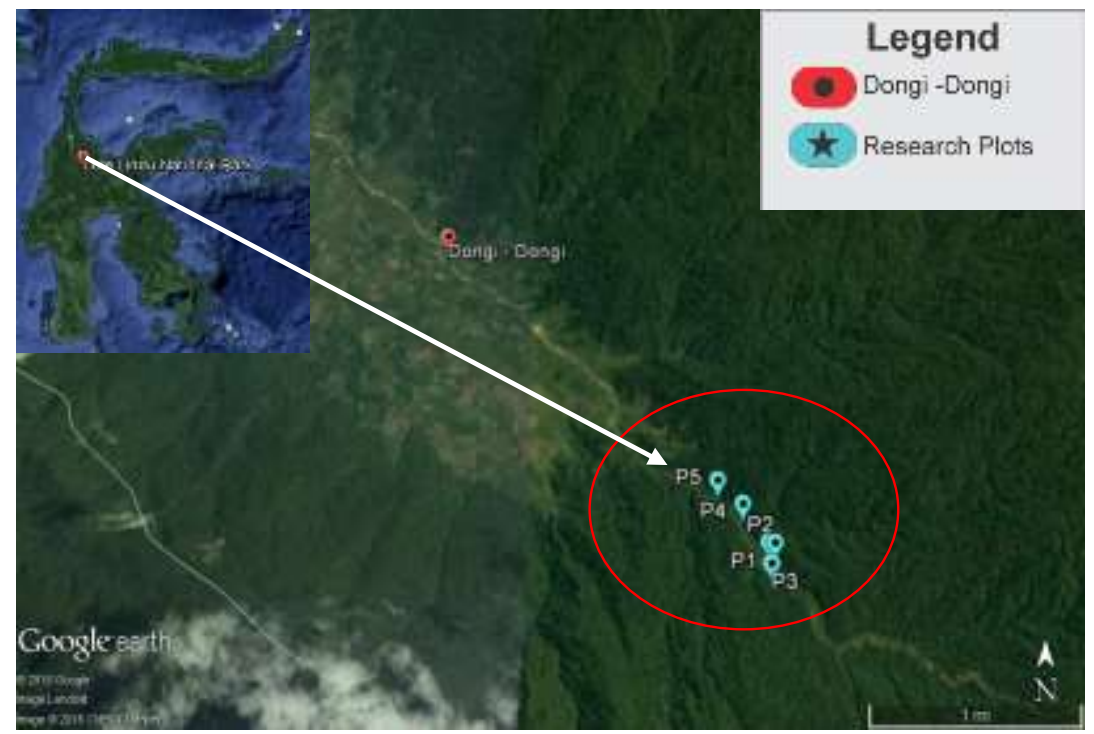

Gambar 1 Letakan plot di lokasi penelitian. P1,P2,P3,P4dan P5 adalah plot pengamatan

Tabel 2 Kondisi suhu udara, kelembaban relatif dan intensitas cahaya di lokasi penelitian

\begin{tabular}{|c|c|c|c|c|}
\hline No & Waktu & $\begin{array}{c}\text { Suhu } \\
\left({ }^{0} \mathrm{C}\right)\end{array}$ & $\begin{array}{c}\text { Kelembaban } \\
(\% \text { rh })\end{array}$ & $\begin{array}{c}\text { Cahaya } \\
(\text { lux })\end{array}$ \\
\hline 1 & 1.00 & $18,6^{0} \mathrm{C}$ & $92,3 \%$ & - \\
\hline 2 & 2.00 & $18,8^{0} \mathrm{C}$ & $93,7 \%$ & - \\
\hline 3 & 3.00 & $19,4^{\circ} \mathrm{C}$ & $90,8 \%$ & - \\
\hline 4 & 4.00 & $19,6^{\circ} \mathrm{C}$ & $90,1 \%$ & - \\
\hline 5 & 5.00 & $19,6^{\circ} \mathrm{C}$ & $90,1 \%$ & - \\
\hline
\end{tabular}

Tabel 2 (Lanjutan)

\begin{tabular}{|c|c|c|c|c|}
\hline 6 & 6.00 & $18,3{ }^{\circ} \mathrm{C}$ & $92,1 \%$ & 297 lux \\
\hline 7 & 7.00 & $19,3{ }^{\circ} \mathrm{C}$ & $90,7 \%$ & 979 lux \\
\hline 8 & 8.00 & $20,4{ }^{0} \mathrm{C}$ & $83,1 \%$ & 995 lux \\
\hline 9 & 9.00 & $21,8{ }^{0} \mathrm{C}$ & $80,7 \%$ & $1346 \operatorname{lux}$ \\
\hline 10 & 10.00 & $22,6{ }^{0} \mathrm{C}$ & $78,8 \%$ & 4755 lux \\
\hline 11 & 11.00 & $24,3^{0} \mathrm{C}$ & $80,1 \%$ & $5561 \operatorname{lux}$ \\
\hline 12 & 12.00 & $25,3^{\circ} \mathrm{C}$ & $96,0 \%$ & $6125 \operatorname{lux}$ \\
\hline 13 & 13.00 & $26,7^{0} \mathrm{C}$ & $79,3 \%$ & 1573 lux \\
\hline 14 & 14.00 & $25,3^{\circ} \mathrm{C}$ & $76,9 \%$ & $1151 \operatorname{lux}$ \\
\hline 15 & 15.00 & $23,2^{\circ} \mathrm{C}$ & $88,0 \%$ & 903 lux \\
\hline 16 & 16.00 & $25,1^{\circ} \mathrm{C}$ & $76,9 \%$ & $876 \operatorname{lux}$ \\
\hline 17 & 17.00 & $25,7^{0} \mathrm{C}$ & $76,5 \%$ & 859 lux \\
\hline 18 & 18.00 & $21,5^{0} \mathrm{C}$ & $76,7 \%$ & $387 \operatorname{lux}$ \\
\hline 19 & 19.00 & $20,8^{\circ} \mathrm{C}$ & $76,9 \%$ & - \\
\hline 20 & 20.00 & $18,2{ }^{\circ} \mathrm{C}$ & $81,2 \%$ & - \\
\hline 21 & 21.00 & $18,0^{0} \mathrm{C}$ & $83,8 \%$ & - \\
\hline 22 & 22.00 & $18,0^{\circ} \mathrm{C}$ & $88,9 \%$ & - \\
\hline 23 & 23.00 & $19,6^{\circ} \mathrm{C}$ & $86,1 \%$ & - \\
\hline 24 & 24.00 & $18,8^{\circ} \mathrm{C}$ & $86,4 \%$ & - \\
\hline \multicolumn{2}{|c|}{ Rata-rata } & $21,20^{\circ} \mathrm{C}$ & $84,84 \%$ & $1985 \operatorname{lux}$ \\
\hline
\end{tabular}

Pengamatan suhu udara dan kelembaban relatif dilakukan tiap jam selama 24 jam (1 Hari), sedangkan intensitas cahaya selama 12 jam (Pagi hingga Sore Hari).
Tabel 3 Kondisi curah hujan di lokasi penelitian

\begin{tabular}{|c|c|c|c|}
\hline \multirow{2}{*}{ No } & \multicolumn{3}{|c|}{ Curah Hujan Bulanan (mm) } \\
\hline & Mei & Mei & Mei \\
\hline 1 & $205 \mathrm{~mm}$ & $164 \mathrm{~mm}$ & $35 \mathrm{~mm}$ \\
\hline
\end{tabular}

Tabel 4 Kondisi pH dan kelembaban tanah di lokasi penelitian

\begin{tabular}{|c|c|c|c|}
\hline No & Plot & pH Tanah & $\begin{array}{c}\text { Kelembaban } \\
\text { Tanah }\end{array}$ \\
\hline 1 & 1 & 6,4 & 55 \\
\hline 2 & 2 & 5,8 & 70 \\
\hline 3 & 3 & 5,9 & 60 \\
\hline 4 & 4 & 5,3 & 58 \\
\hline 5 & 5 & 4,7 & 65 \\
\hline \multicolumn{2}{|c|}{ Rata-rata } & 5,62 & 61,6 \\
\hline
\end{tabular}

Sampel tanah yang diambil pada lokasi penelitian menggunakan metode disturbed soil sample (contoh tanah terganggu) dengan pengambilan secara random simple sampling (acak sederhana) kemudian dikompositkan dan sampel tanah dianalisis di Laboratorium Ilmu Tanah Fakultas Pertanian UNTAD Palu untuk melihat unsur kimia seperti kadar Nitrogen, Posfor dan Kalium di dalam tanah dengan 
metode khjeldhal untuk Nitrogen dan metode ekstraksi dengan HCL 25\% untuk Posfor dan Kalium. Berikut hasil data analisis faktor kimia tanah yang meliputi nitrogen, posfor dan kalium, di sajikan dalam tabel 5 :

Tabel 5 Konsentrasi nitrogen, posfor \& kalium pada tanah tempat tumbuh $P$. elata (Mart.) $\mathrm{H}$. Wendl

\begin{tabular}{|c|c|c|c|c|}
\hline \multirow{2}{*}{ No } & \multirow{2}{*}{$\begin{array}{c}\text { Kode } \\
\text { Sampel }\end{array}$} & $\begin{array}{c}\text { Nitrogen } \\
(\text { N-Tot) }\end{array}$ & $\begin{array}{c}\text { Kalium } \\
\text { (K-Tot) }\end{array}$ & $\begin{array}{c}\text { Posfor } \\
\text { (P-Tot) }\end{array}$ \\
\cline { 3 - 5 } & & $\%$ & $\mathrm{mg} / 100 \mathrm{~g}$ & $\mathrm{mg} / 100 \mathrm{~g}$ \\
\hline 1 & Dg 1 & 0,08 & 39,16 & 34,22 \\
\hline
\end{tabular}

Universitas Tadulako 2016

\section{Faktor Lingkungan Biotik}

Kondisi vegetasi pada lokasi penelitian untuk melihat berbagai jenis tumbuhan di sekitar $P$. elata, didapatkan dari pengambilan sampel dengan menggunakan metode petak ganda dengan perletakan secara "Purposive Sampling".

Jumlah individu dan diameter serta jumlah plot ditemukannya tiap jenis tumbuhan pada tingkat Pohon, Tiang, Pancang dan Seedling atau tumbuhan bawah diambil, untuk menghitung Kerapatan, Frekuensi, Dominansi untuk mempermudah mendapatkan Indeks Nilai Penting dari jenis-jenis vegetasi tumbuhan tersebut.

Berikut ini adalah hasil analisis vegetasi yang ditemukan di sekitar $P$. elata. meliputi tingkat Pohon (20 x $20 \mathrm{~m})$, Tiang (10 x 10 m), Pancang (5 x 5 m) dan Seedling atau tumbuhan bawah (2 $\times 2 \mathrm{~m})$, disajikan dalam tabel 6 sampai 9 sebagai berikut :

Tabel 6 Tumbuhan tingkat pohon yang hidup bersama dengan $P$. elata (Mart.) H. Wendl., pada areal plot $20 \mathrm{x}$ $20 \mathrm{~m}$

\begin{tabular}{|c|l|l|c|c|c|c|c|}
\hline NO & NAMA SPECIES & FAMILI & $\begin{array}{c}\text { KR } \\
(\%)\end{array}$ & $\begin{array}{c}\text { FR } \\
(\%)\end{array}$ & $\begin{array}{c}\text { DR } \\
(\%)\end{array}$ & $\begin{array}{c}\text { INP } \\
(\%)\end{array}$ & H' \\
\hline 1 & $\begin{array}{l}\text { Castanopsis acuminatissima (Blume) } \\
\text { A. DC. }\end{array}$ & Fagaceae & 10,99 & 11,76 & 11,48 & 34,23 & 0,25 \\
\hline 2 & $\begin{array}{l}\text { Polyalthia rumphii (Blume ex } \\
\text { Hench/) Merr. }\end{array}$ & Annonaceae & 10,99 & 8,82 & 10,82 & 30,64 & 0,23 \\
\hline 3 & Ficus Sp. 1 & Moraceae & 8,79 & 5,88 & 14,23 & 28,90 & 0,23 \\
\hline 4 & Ficus Sp. 2 & Moraceae & 8,79 & 8,82 & 9,40 & 27,01 & 0,22 \\
\hline 5 & Ficus variegata Blume. & Moraceae & 9.89 & 5.88 & 8.22 & 23.99 & 0.20 \\
\hline 6 & $\begin{array}{l}\text { Macaranga hispida (Blume) Mull. } \\
\text { Arg. }\end{array}$ & Euphorbiaceae & 3.30 & 8.82 & 3.98 & 16.10 & 0.16 \\
\hline 7 & Adinandra celebica Koord. & Pentaphylacaceae & 6.59 & 5.88 & 3.51 & 15.99 & 0.16 \\
\hline 8 & Nauclea sp. & Rubiaceae & 4.40 & 8.82 & 2.54 & 15.76 & 0.15 \\
\hline 9 & $\begin{array}{l}\text { Acmena acuminatissima(Blume) } \\
\text { Merr. \& L. M. Perry }\end{array}$ & Myrthaceae & 4.40 & 8.82 & 2.29 & 15.50 & 0.15 \\
\hline 10 & Eucalyptus deglupta Blume. & Myrthaceae & 4.40 & 5.88 & 3.47 & 13.75 & 0.14 \\
\hline 11 & Adinandra masambensis Kobuski. & Pentaphylacaceae & 2.20 & 5.88 & 1.34 & 9.42 & 0.11 \\
\hline \multicolumn{1}{|l}{ Jumlah } & & 100 & 100 & 100 & 300 & 2,00 \\
\hline
\end{tabular}


Tabel 7 Tumbuhan tingkat tiang yang hidup bersama dengan P. elata (Mart.) H. Wendl., pada areal plot 10 x 10

\begin{tabular}{|c|l|l|c|c|c|c|c|}
\hline NO & \multicolumn{1}{|c|}{ NAMA SPECIES } & FAMILI & $\begin{array}{c}\text { KR } \\
(\%)\end{array}$ & $\begin{array}{c}\text { FR } \\
(\%)\end{array}$ & $\begin{array}{c}\text { DR } \\
(\%)\end{array}$ & $\begin{array}{c}\text { INP } \\
(\%)\end{array}$ & H' \\
\hline 1 & Eurya acuminata DC. & Theaceae & 19,30 & 16,67 & 28,06 & 64,02 & 0,33 \\
\hline 2 & Ficus sp. 4 & Moraceae & 17,54 & 22,22 & 17,81 & 57,58 & 0,32 \\
\hline 3 & Adinandra celebica Koord. & Pentaphylacaceae & 22,81 & 11,11 & 22,00 & 55,92 & 0,31 \\
\hline 4 & Macaranga hispida (Blume) Mull. Arg. & Euphorbiaceae & 8,77 & 11,11 & 7,75 & 27,64 & 0,22 \\
\hline 5 & Ficus sp. 5 & Moraceae & 7,02 & 11,11 & 7,17 & 25,30 & 0,21 \\
\hline 6 & Ficus sp. 3 & Moraceae & 10,53 & 5,56 & 6,40 & 22,49 & 0,19 \\
\hline 7 & Pandanus sarasinorum Warb. & Pandaceae & 7,02 & 5,56 & 5,85 & 18,42 & 0,17 \\
\hline 8 & Ficus sp. 2 & Moraceae & 3,51 & 5,56 & 3,34 & 12,41 & 0,13 \\
\hline 9 & Sambucus javanica Reinw ex. Blume & Adoxaceae & 1,75 & 5,56 & 0,83 & 8,14 & 0,10 \\
\hline 10 & Ficus sp. 1 & Moraceae & 1,75 & 5,56 & 0,79 & 8,10 & 0,10 \\
\hline & \multicolumn{2}{|c|}{ Jumlah } & 100 & 100 & 100 & 300 & 2,08 \\
\hline
\end{tabular}

Tabel 8 Tumbuhan tingkat pancang yang hidup bersama dengan P. elata (Mart.) H. Wendl., pada areal plot $5 \mathrm{x}$ $5 \mathrm{~m}$

\begin{tabular}{|c|l|l|c|c|c|c|c|}
\hline NO & \multicolumn{1}{|c|}{ NAMA SPECIES } & FAMILI & $\begin{array}{c}\text { KR } \\
(\boldsymbol{\%})\end{array}$ & $\begin{array}{c}\text { FR } \\
(\boldsymbol{\%})\end{array}$ & $\begin{array}{c}\text { DR } \\
(\boldsymbol{\%})\end{array}$ & $\begin{array}{c}\text { INP } \\
(\boldsymbol{\%})\end{array}$ & H' \\
\hline 1 & Trema orientalis (L.) Blume. & Cannabaceae & 25,49 & 14,29 & 25,19 & 64,97 & 0,33 \\
\hline 2 & Ficus sp. 4 & Moraceae & 7,84 & 14,29 & 20,80 & 42,93 & 0,28 \\
\hline 3 & Breynia microphylla (T\&B) Muell. Arg. & Euphorbiaceae & 11,76 & 7,14 & 14,30 & 33,21 & 0,24 \\
\hline 4 & Medinilla horridum Bakh. F. & Melastomataceae & 9,80 & 7,14 & 14,64 & 31,59 & 0,24 \\
\hline 5 & Pipturus argenteus (G. Forst.) Wedd. & Urticaceae & 19,61 & 7,14 & 1,60 & 28,36 & 0,22 \\
\hline 6 & Ficus sp. 5 & Moraceae & 9,80 & 7,14 & 5,32 & 22,27 & 0,19 \\
\hline 7 & Endiandra velutina Kosterm. & Lauraceae & 3,92 & 7,14 & 6,09 & 17,15 & 0,16 \\
\hline 8 & Phoebe grandis (Ness) Merr. & Lauraceae & 3,92 & 7,14 & 2,86 & 13,92 & 0,14 \\
\hline 9 & Mallotus barbatus Mull. Arg. & Euphorbiaceae & 1,96 & 7,14 & 4,59 & 13,70 & 0,14 \\
\hline 10 & Acer laurinum Hassk. & Aceraceae & 1,96 & 7,14 & 1,67 & 10,77 & 0,12 \\
\hline 11 & Saurauia sp. & Actinidiaceae & 1,96 & 7,14 & 1,60 & 10,70 & 0,12 \\
\hline 12 & Blumea balcamifera (L.) DC. & Asteraceae & 1,96 & 7,14 & 1,33 & 10,43 & 0,12 \\
\hline & & 100 & 100 & 100 & 300 & 2,31 \\
\hline
\end{tabular}

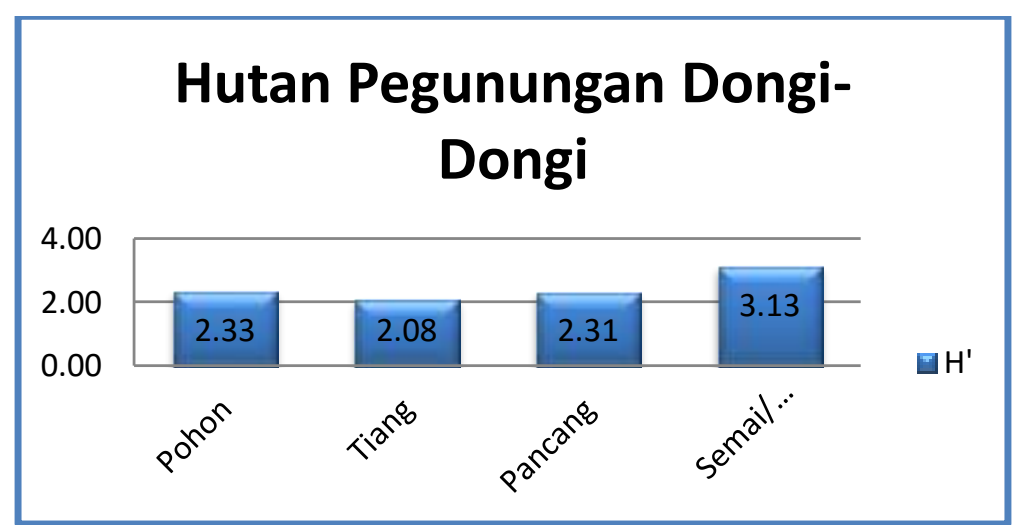

Gambar 2 Persentase nilai indeks keanekaragaman spesies pada berbagai tingkat pertumbuhan 
Tabel 9 Tumbuhan tingkat seedling atau tumbuhan bawah yang hidup bersama dengan P. elata (Mart.) H. Wendl., pada areal plot 2 × $2 \mathrm{~m}$

\begin{tabular}{|c|c|c|c|c|c|c|}
\hline No & NAMA SPECIES & FAMILI & $\begin{array}{l}\text { KR } \\
(\%)\end{array}$ & $\begin{array}{c}\text { FR } \\
(\%) \\
\end{array}$ & $\begin{array}{l}\text { INP } \\
(\%)\end{array}$ & $\mathbf{H}^{\prime}$ \\
\hline 1 & Ageratum conyzoides L. & Asteraceae & 12,00 & 5,88 & 17,88 & 0,22 \\
\hline 2 & Cuphea balsamona Cham. \& Schltdl. & Lythraceae & 10,40 & 5,88 & 16,28 & 0,20 \\
\hline 3 & Impatiens platypetala Lindl. & Balsaminaceae & 8,80 & 5,88 & 14,68 & 0,19 \\
\hline 4 & Crassocephalum crepidiodes (Benth.)S. Moore & Asteraceae & 8,00 & 5,88 & 13,88 & 0,19 \\
\hline 5 & Paspalum conjugatum P. J. Bergius & Poaceae & 8,00 & 5,88 & 13,88 & 0,19 \\
\hline 6 & Sphenomeris chinensis (L.) Maxon & Lindsaeaceae & 4,00 & 5,88 & 9,88 & 0,15 \\
\hline 7 & Desmodium repandum (Vahl.) DC. & Apilionaceae & 6,40 & 2,94 & 9,34 & 0,14 \\
\hline 8 & Rubus moluccanus auct. & Rocaceae & 2,40 & 5,88 & 8,28 & 0,13 \\
\hline 9 & Nephrolepis biserrata (Sw.) Schott & Nephrolepidaceae & 2,40 & 5,88 & 8,28 & 0,13 \\
\hline 10 & Cyanthillium cinereum (L.) H. Roxb. & Asteraceae & 4,00 & 2,94 & 6,94 & 0,12 \\
\hline 11 & Acmella ciliata (Kunth.) Cass. & Asteraceae & 4,00 & 2,94 & 6,94 & 0,12 \\
\hline 12 & Bidens pilosa $\mathrm{L}$. & Asteraceae & 4,00 & 2,94 & 6,94 & 0,12 \\
\hline 13 & Poikilospermum suaveolen (Blume) Merr. & Urticaceae & 4,00 & 2,94 & 6,94 & 0,12 \\
\hline 14 & Trema tomentosa (Roxb.) H. Hara & Cannabaceae & 2,40 & 2,94 & 5,34 & 0,10 \\
\hline 15 & Desmodium sp. & Fabaceae & 2,40 & 2,94 & 5,34 & 0,10 \\
\hline 16 & Acmella uliginosa (Sw.) Cass. & Asteraceae & 2,40 & 2,94 & 5,34 & 0,10 \\
\hline 17 & Gonostegia hirta (Blume ex Hassk.) Miq. & Urticaceae & 2,40 & 2,94 & 5,34 & 0,10 \\
\hline 18 & Cissus sp. & Vitaceae & 2,40 & 2,94 & 5,34 & 0,10 \\
\hline 19 & Solanum nigrum L. & Solanaceae & 2,40 & 2,94 & 5,34 & 0,10 \\
\hline 20 & Polygala paniculata L. & Polygalaceae & 1,60 & 2,94 & 4,54 & 0,09 \\
\hline 21 & Macaranga hispida (Blume) Mull. Arg. & Euphorbiaceae & 1,60 & 2,94 & 4,54 & 0,09 \\
\hline 22 & Rubus fraxinifolius Poir. & Rocaceae & 0,80 & 2,94 & 3,74 & 0,07 \\
\hline 23 & Begonia aptera Blume & Begoniaceae & 0,80 & 2,94 & 3,74 & 0,07 \\
\hline 24 & Elephantopus mollis Kunth. & Asteraceae & 0,80 & 2,94 & 3,74 & 0,07 \\
\hline 25 & Alpinia eremochlamys K. Schum & Zingiberaceae & 0,80 & 2,94 & 3,74 & 0,07 \\
\hline 26 & Diplazium esculentum (Retz) Sw. & Athyriaceae & 0,80 & 2,94 & 3,74 & 0,07 \\
\hline \multicolumn{2}{|r|}{ Jumlah } & 100 & 100 & 100 & 200 & 3,13 \\
\hline
\end{tabular}

\section{Pembahasan}

Ekologi adalah ilmu yang mempelajari hubungan timbal balik antar organisme yang satu dengan organisme yang lain serta lingkungannya (Kendeigh, 1980). Hubungan timbal balik ini dalam cara-caranya berhubungan dengan organisme lain maupun dengan semua komponen lingkungannya. Hubungan timbal balik atau yang dikenal interkasi antara organisme dengan lingkungannya, sesungguhnya merupakan hubungan yang sangat erat dan kompleks. Autekologi yaitu ekologi yang mempelajari suatu spesies organisme atau organisme secara individu yang berinteraksi dengan lingkungannya. Dari segi autekologi mempelajari sejarah hidup suatu spesies organisme, perilaku, dan pengaruh suatu faktor lingkungan terhadap hidup dan tempat tumbuhnya (Odum, 1993).

\section{a. Faktor Lingkungan Abiotik}

Pigafetta elata (Mart.) H. Wendl. tumbuh subur di daerah hutan hujan pegunungan (pegunungan yang lembab), keadaan topografi area tempat tumbuhnya $P$. 
elata (Mart.) H. Wendl pada Hutan Pegunungan Dongi-dongi termasuk datar, berbukit sampai curam berbukit dengan kelerengan berkisar antar $0-50^{\circ}$ dan terletak pada ketinggian 1200-1500 m dpl.

Suhu udara pada lokasi penelitian $P$. elata, berkisar antara $18{ }^{\circ} \mathrm{C}$ (21.00 dan 22.00 WITA) untuk yang terendah sampai $26,7{ }^{\circ} \mathrm{C}$ (13.00 WITA) untuk yang tertinggi dengan suhu rata-rata $21,20{ }^{\circ} \mathrm{C}$. Untuk kelembaban relatif (Rh) berkisar antara 76,5\%-93,7\% dengan rata-rata $84,84 \%$ dan curah hujan pada waktu penelitian pada bulan Mei, Juni dan Juli yaitu $205 \mathrm{~mm}, 164 \mathrm{~mm}$ dan terendah pada bulan Juli yaitu $35 \mathrm{~mm}$. Hal ini masih dalam keadaan yang stabil untuk pertumbuhan $P$. elata. Menurut Blombery dan Rodd (1992), bahwa P. elata (Mart.) H. Wendl tumbuh subur pada iklim tropis lembab di mana suhu tidak pernah turun di bawah $10^{\circ} \mathrm{C}$, dengan curah hujan tahunan $1500 \mathrm{~mm}$ atau lebih dan curah hujan bulanan $25 \mathrm{~mm}$ atau lebih.

Untuk intensitas cahaya sendiri pada lokasi P. elata tumbuh antara 297 lux ( pada pukul 06.00 pagi hari) hingga 6125 lux (pada pukul 1200 siang hari) dengan rata-rata 1985 lux. Kondisi ini pun masih tergolong normal, karena $P$. elata membutuhkan cahaya penuh dan tumbuh dengan baik pada sinar matahari langsung (Blombery dan Rodd, 1992).
Derajat keasaman $(\mathrm{pH})$ dan kelembaban tanah pada hasil pengamatan di lokasi tumbuhnya $P$. elata, yaitu Plot $1 \mathrm{pH}$ 6,4 kelembaban $55 \%$, Plot $2 \mathrm{pH} 5,8$ kelembaban $70 \%$, Plot 3 pH 5,9 kelembaban $60 \%$, Plot 4 pH 5,3 kelembaban $58 \%$ dan Plot 5 pH 4,7 kelembaban $65 \%$ serta secara keseluruhan dari tiap plot, rata-rata $\mathrm{pH}$ dan kelembaban tanah yaitu 5,62 dan 61,6\%. Dataran rendah mencapai pH 8,07 sedangkan dataran tinggi mencapai 7,56. $\mathrm{pH}$ tanah menunjukkan derajat keasaman tanah atau keseimbangan antara konsentrasi $\mathrm{H}+$ dan $\mathrm{OH}-$ dalam larutan tanah. $\mathrm{pH}$ tanah sangat menentukan pertumbuhan dan produksi daun, bahkan berpengaruh pula pada kualitas kehijauan daun. $\mathrm{pH}$ tanah yang optimal bagi pertumbuhan kebanyakan tanaman adalah antara $5.6-6.0$. Bila tanah bersuasana basa ( $\mathrm{pH}>7.0$ ) biasanya tanah tersebut kandungan kalsiumnya tinggi, sehingga terjadi fiksasi terhadap fosfat dan tanaman pada tanah basa seringkali mengalami defisiensi unsur $\mathrm{P}$ (Rachmawati, 2009).

$$
\text { Menurut Hardjowigeno (2007), }
$$

kesuburan tanah merupakan kemampuan tanah menyediakan unsur hara yang dibutuhkan oleh tanaman untuk mendukung pertumbuhan dan reproduksinya. Unsur hara dalam bentuk nutrisi dapat diserap oleh tanaman melalui akar. Nutrisi dapat diartikan sebagai proses untuk memperoleh 
nutrien, sedangkan nutrien dapat diartikan sebagai zat-zat yang diperlukan untuk kelangsungan hidup tanaman berupa mineral dan air. Untuk hasil analisis sifat kimia yang berada di dalam tanah tempat $P$. elata (Mart.) H. Wendl tumbuh, yaitu Nitrogen (N-Tot) 0,08 \%, Posfor (P-tot) 39,16 $\mathrm{mg} / 100 \mathrm{~g}$ dan Kalium (K-Tot) 34,22 $\mathrm{mg} / 100 \mathrm{~g}$ (tabel 4.6). Hasil analisis sifat kimia tanah memperlihatkan unsur hara $\mathrm{N}$ rendah bahkan sangat rendah, hal ini diduga karena proses perombakan bahan organik berjalan lambat. Menurut Hakim et al. (1986), sejumlah besar nitrogen di dalam tanah berada dalam bentuk bahan organik. Dengan demikian dekomposisi nitrogen merupakan sumber utama nitrogen tanah, di samping berasal dari air hujan. Demikian pula, halnya dengan unsur Posfor (P), menurut Hardjowigeno (1995), sebab kekurangan Posfor di dalam tanah adalah jumlah P di tanah relatif sedikit dan sebagian besar terdapat dalam bentuk yang sukar diambil oleh tanaman. Pada tanah masam unsur P tidak dapat diserap tanaman karena diikat (difiksasi) oleh $\mathrm{Al}$, sehingga ketersediannya rendah. Tetapi pada penelitian ini, unsur $\mathrm{P}$ masih dalam tingkatan sedang sehingga masih dapat diserap oleh tumbuhan di sekitar termasuk P. elata Untuk unsur Kalium (K-Tot), masih relatif tinggi dengan persentasi sebesar $34,22 \mathrm{mg} / 100 \mathrm{~g}$.

\section{b. Faktor Lingkungan Biotik}

Faktor vegetasi tumbuhan di daerah sekitar tempat tumbuhnya Pigafetta elata (Mart.) H. Wendl., meliputi beberapa tingkatan tumbuhan yaitu tingkat pohon, pancang, tiang dan semai/seedling. Pada setiap tingkatan tumbuhan akan diketahui Indeks Nilai Penting (INP) untuk menetapkan dominasi suatu jenis terhadap jenis lainnya atau dengan kata lain nilai penting menggambarkan kedudukan ekologis suatu jenis dalam komunitas. Indeks Nilai Penting dihitung berdasarkan penjumlahan nilai kerapatan relatif (KR), frekuensi relatif (FR) dan dominansi relatif (DR) yang jika dijumlahkan akan bernilai 300 persen berlaku untuk tingkatan pohon, tiang dan pancang, sedangkan untuk semai/seedling didasarkan pada penjumlahan kerapatan relatif (KR) dan frekuensi relatif (FR) dengan jumlah akhir INP 200 persen (Soerianegara dan Indrawan, 2005).

Pada jenis-jenis tumbuhan tingkatan pohon $(\mathrm{DBH}>20 \mathrm{~cm}$ ) yang berada di sekitar $P$. elata, ada 11 jenis tumbuhan dengan jenis yang dominan berdasarkan nilai INP tertinggi, yaitu Castanopsis acuminatissima (Blume) A. DC dan yang terendah adalah Adinandra masambensis Kobuski. . Hal ini juga diperjelas pada gambar 4.3, yang mana suku Fagaceae dengan jenis $C$. acuminatissima (Blume) A. DC. 
mendapatkan INP tertinggi yaitu 34,23\% sementara suku Pentaphylacaceae dengan jenis Adinandra masambensis Kobuski. mendapatkan INP terendah yaitu $9,42 \%$. Olehnya $C$. acuminatissima dapat dikatakan mendominasi di sekitar P. elata pada strata pohon di lokasi penelitian. Ramadanil P. (2010) dalam penelitiannya menyatakan bahwa pada hutan lokasi penelitian anggrek endemik di Taman Nasional Lore Lindu, vegetasinya didominasi oleh famili Fagaceae. Hal ini mengindikasikan bahwa komposisi jenis tumbuhan di Sulawesi menunjukan pola yang berbeda dengan bagian barat Indonesia yang umumnya di dominasi oleh famili Dipterocarpaceae (Kartawinata dkk, 2004).

Pada vegetasi tumbuhan tingkatan tiang (DBH 10-19,9 cm) di area penelitian, tersusun atas 10 jenis tumbuhan. Jenis yang memiliki INP tertinggi adalah Eurya acuminata DC. (Theaceae) dan tumbuhan yang memiliki INP terendah adalah Ficus sp. 1 (Moraceae). Dari data tersebut terlihat bahwa jenis tumbuhan E. acuminata DC. (Theaceae) yang mendominasi di sekitar $P$. elata pada lokasi penelitian dengan INP tertinggi pada strata tiang. Secara keseluruhan, pada tingkatan tiang ini banyak ditemukan suku Moraceae yakni 5 jenis Ficus sp. yang belum teridentifikasi hingga spesies (Gambar 4.4). Saleh (2013), dalam penelitian Autekologi Nephentes Pitopangii
Lee di kawasan TNLL, menemukan untuk tumbuhan tingkat tiang (DBH 10-19,9 cm) tercatat sebanyak 18 jenis yang jenis vegetasi tingkat tiang yang dominan juga adalah Eurya accuminata (Theaceae).

Pada tingkatan pancang $(2-9,9 \mathrm{~cm})$, vegetasi tumbuhan di lokasi penelitian tersusun atas 12 jenis. Jenis tumbuhan dengan INP tertinggi di dominasi oleh Trema orientalis (L.) Blume. (Cannabaceae) 64,97 \% dan Ficus sp.4 (Moraceae) 42,93 $\%$, sedangkan jenis tumbuhan dengan INP terendah pada strata pancang adalah Blumea balcamifera (L.) DC. 10,43 \%. Pada hasil pengamatan jenis tumbuhan tingkatan pancang di sekitar lokasi penelitian $P$. elata .ini, didominasi oleh $T$. orientalis (L.) Blume. Tumbuhan ini merupakan jenis paling dominan pada tingkat pohon, tiang dan pancang yang diketahui banyak tumbuh di hutan hujan dataran rendah dan ada pula di dataran tinggi serta masuk tumbuhan pionir pada lahan terbuka. Sistem perakaran yang kuat memungkinkan $T$. orientalis bertahan di lingkungan yang kering bahkan tanah miskin hara, namun vegetasi ini tidak toleran terhadap api (Orwa et al., 2009).

Dari hasil pengamatan di lokasi penelitian, ditemukan sebanyak 26 jenis tumbuhan bawah/seedling dari 24 marga dan 19 suku. Jenis tumbuhan penyusun lantai hutan di lokasi penelitian (tabel 4.10), yang mana jenis tumbuhan yang memiliki INP 
tertinggi adalah Ageratum conyzoides L. (Asteraceae) 17,88 \% dan Cuphea balsamona Cham. \& sSchltdl. (Lythraceae) $16,28 \%$. Sedangkan jenis tumbuhan dengan nilai INP terendah yaitu Rubus fraxinifolius Poir. (Rocaceae) 3,74 \%, Begonia aptera Blume. (Begoniaceae) 3,74 \%, Elephantopus mollis Kunth (Asteraceae) $3,74 \%$, Alpinia eremochlamys K. Schum (Zingiberaceae) $3,74 \%$ dan Diplazium esculentum (Retz) Sw. (Athyriaceae) 3,74 $\%$. Pada penelitian ini, jenis tumbuhan tingkatan semai/seedling yang berada di sekitar P. elata, didominasi oleh Ageratum conyzoides $\mathrm{L}$. Jenis ini merupakan jenis dari suku Asteraceae yang banyak di temukan di daerah kebun-kebun, bekas perladangan, hutan sekunder dan sebagainya. Ageratum conyzoides L., berasal dari Amerika tropis, dan di Indonesia tanaman ini merupakan tanaman liar dan lebih dikenal sebagai tumbuhan pengganggu atau gulma di kebun dan ladang. Ageratum conyzoides L. (Bandotan) merupakan gulma semusim, dan tumbuh liar di tempat-tempat terbuka atau agak terlindung seperti di ladang-ladang dan kebun-kebun. Tumbuh dari dataran rendah sampai ketinggian di atas $2.100 \mathrm{~m} \mathrm{dpl}$ (Djauhariya, 2004).

Berdasarkan hasil analisis vegetasi dari semua tingkatan tumbuhan di sekitar $P$. elata di temukan 52 jenis tumbuhan dari 43 marga dan 31 suku. Jenis-jenis tumbuhan di lokasi penelitian didominasi oleh spesiesspesies dari tingkat semai/seedling dengan nilai indeks keanekaragaman 3,13, diikuti pohon (2,33), pancang $(2,31)$ dan tiang $(2,08)$. Keanekaragaman spesies di lokasi penelitian berdasarkan indeks keanekaragaman spesies Shannon-Winner termasuk dalam kategori sedang sampai tinggi dengan nilai indeks sebesar 2,083,33 . Keanekaragaman spesies di sekitar tempat tumbuhnya $P$. elata yang tertinggi berada pada tingkat semai/tumbuhan bawah, sedangkan keanekaragaman spesies terendah didapatkan pada tingkat tiang. Hal ini menunjukan bahwa tingginya indeks kenakaragaman dipengaruhi oleh jumlah individu serta penyebaran jenis vegetasinya. Nilai indeks kenekaragaman jenis menunjukan stabilitas kompleksitas ekosistem tersebut. Semakin tinggi nilai indek keanekaragaman maka ekosistem di wilayah tersebut juga semakin baik. Barbour et al. (1987) mengklasifikasikan nilai indeks keanekaragaman jenis Shanon (H') atas 3 kategori yaitu $\mathrm{H}^{\prime}=<1$ (rendah), $\mathrm{H}^{\prime}=2-3$ (sedang), $\mathrm{H}^{\prime}=>3$ (tinggi).

Kesimpulan yang diambil berdasarkan hasil pengamatan dan pembahasan di atas adalah sebagai berikut.

a. Pigafetta elata (Mart.) H. Wendl. tumbuh subur di daerah hutan hujan pegunungan (pegunungan yang lembab), dengan keadaan topografi area tempat 
tumbuhnya $P$. elata (Mart.) H. Wendl pada Hutan Pegunungan Dongi-dongi termasuk datar, berbukit sampai curam berbukit dengan kelerengan berkisar antar $0-50^{\circ}$ serta berkisar pada ketinggian 1200 - $1500 \mathrm{~m}$ dpl, dengan suhu rata rata $21,20{ }^{\circ} \mathrm{C}$ dan kelembaban $84,84 \%$, curah hujan bulanan Mei sampai Juli 2016 yaitu $205 \mathrm{~mm}, 134 \mathrm{~mm}$ dan $35 \mathrm{~mm}$ dan intensitas cahaya berkisar $297-6125$ lux dengan rata-rata 1985 lux. Pigafetta elata dapat tumbuh di N, P, K tanah dengan konsentrasi yang bervariasi yaitu N-Tot $0,08 \%$ (sangat rendah), P-Tot $39,16 \mathrm{mg} / 100 \mathrm{~g}$ (sedang) dan K-Tot 34,22 $\mathrm{mg} / 100 \mathrm{~g}$ (tinggi).

b. Analisis vegetasi pada lokasi penelitian tempat Pigafetta elata (Mart.) H. Wendl tumbuh yaitu dari tingkat pohon, vegetasi didominasi oleh Castanopsis acuminatissima (Blume) A. DC. dengan INP $34,23 \%$, tingkat tiang Eurya acuminata DC. INP 64,02\% , tingkat pancang Trema orientalis (L.) Blume INP $64.97 \%$ dan Ageratum conyzoides L. INP $17.88 \%$ mendominasi vegetasi pada tingkat semai.

c. Jenis-jenis tumbuhan di sekitar P. elata (Mart.) H. Wendl yang mempunyai indeks keanekaragaman yang tinggi berada pada tingkat semai atau tumbuhan bawah 3,13.
Diharapkan agar dapat melakukan penelitian lanjut mengenai aspek anatomi, fisiologi dan fitokimia serta ekologinya kembali P. elata (Mart.) H. Wendl agar dapat dijadikan bahan referensi untuk ilmu pengetahuan di masa yang akan datang dan juga di harapkan dapat menjaga serta melindungi $P$. elata yang merupakan tumbuhan bersifat endemik di Sulawesi.

\section{UCAPAN TERIMA KASIH}

Penulis menghargai dan mengucapkan terima kasih kepada sahabat-sahabat yang telah membantu pengambilan data di lapangan.

\section{DAFTAR PUSTAKA}

Blombery, A. and Rodd, T. (1992). An Informative, Practical Guide to Palms of The World Their Cultivation, Care \& Landscape Use. Sidney. Australia: Angus \& Robertson. Page 297

[Dephut] Departemen Kehutanan. (2015). Buku Panduan Wisata Taman Nasioanal Lore Lindu. Balai Besar Taman Nasional Lore Lindu. Palu.

[Dephut] Departemen Kehutanan. (2016). Kawasan Taman Nasional Lore Lindu. Palu: Balai Besar Taman Nasional Lore Lindu.

Djauhariyah, (2004). Gulma Berkhasiat Obat. Jakarta: Penebar Swadaya. Hal. 57

Dransfield, J. (1998). Pigafetta. Principes. Royal Botanic Garden, Kew Richmond, Surrey, TW9 SAE, UK. Vol. 42(1) 34-40.

Dransfield, J., Uhl, N. W., Asmussen, C. B., Baker, W. J., Harley, M. M., \& Lewis, C. E. (2008). Genera Palmarum. Royal Botanic Garden, Kew. 
Kartawinata K, Samsoedin I, Heriyanti M and Afriastini JJ. (2004). A tree species inventory in a hectare plot at the Batang Gadis National Park. North Sumatra. Indonesia. Reinwardtia 12 : 145-157

Kendeigh, S., C., (1980). Ecology with Special Reference to Animal and Man. Departement of Zoological University of Illinoist at Urbana-Champaign. New Delhi: Pretince-Hall of India Privated Limited.

Ludwig, J.A., and J. F. Reynolds. (1988). Statistical Ecology A Primer On Methods and Computing. John Wiley \& Sons, Inc. Canada.

Mogea J. P. (2002). Preliminary Study On The Palm Flora Of The Lore Lindu National Park, Central Sulawesi, Indonesia. Herbarium Bogoriense, Research Center for Biology, LIPI, Bogor. Indonesia. BIOTROPIA No. 18, 1-20.

Odum, E.P. (1993). Dasar-Dasar Ekologi. Edisi ketiga. Gajah mada University Press. Jogjakarta.

Orwa, C., Mutua, A., Kindt, R., Jamnadass, R., Anthony, S. (2009). Agroforestree Database: a tree reference and selection guide version 4.0. Kenya: World Agroforestry Centre.

Pitopang, R. (2006). Stucture and Composition of Six Land Use Types in The Lore Lindu National Park, Central Sulawesi, Indonesia. Disertasi Program Doktor. Institut Pertanian Bogor.

Pitopang, R. (2010). Kajian Beberapa Aspek Botani Anggrek Endemik Coelogyne celebensis J.J. Sm. Dari Taman Nasional Lore Lindu Sulawesi Tengah. Jurnal Biocelebes. Vol. 4(1) 1-13.

Pitopang R. (2012). Struktur Dan Komposisi Vegetasi Pada 3 Zona Elevasi Yang Berbeda Di Taman Nasional Lore Lindu Sulawesi Tengah Indonesia. Jurnal Natural Science. Vol. 1.(1) 85105.
Purwaningsih, Razali, Y. (2005). Komposisi Jenis dan Struktur Vegetasi Hutan di Kawasan Pakuli, Taman Nasional Lore Lindu, Sulawesi Tengah, $J$. Biodiversitas, Vol.6 (2) : 123-128.

Rahmawati, I. (2009). Tanggapan Pertumbuhan Sansevieria spp terhadap Logam Timbal $(\mathrm{Pb})$ dari Asap Kendaraan Bermotor 2 Tak. Jogjakarta: UGM

Saleh, M., M., F., R., Miswan, R., Pitopang. (2013). Autekologi Nepenthes pitopangii Lee. di Kawasan Taman Nasional Lore Lindu. Jurnal Natural Science. Vol.2.(2).

Soerianegara, I., dan Indrawan A. (1993). Ekologi Hutan. Bogor :IPB (Institut pertanian Bogor).

Soerianegara, I., dan Indrawan A. (2005). Ekologi Hutan Indonesia. Bogor : Fakultas Kehutana Institut Pertanian Bogor.

Suganda S., Achmad R., dan Sutono. (2006). Petunjuk Pengambilan Contoh Tanah, Sifat Fisik Tanah dan Metode Analisisnya. Balai Besar Litbang Sumberdaya Lahan Pertanian, Badan Penelitian dan Pengembangan Pertanian, Departemen Pertanian. 